\title{
"Momentum and contrarian effects in the Ukrainian stock market: case of daily overreactions"
}

\begin{tabular}{|c|c|}
\hline \multirow{8}{*}{ AUTHORS } & Alex Plastun iD https://orcid.org/0000-0001-8208-7135 \\
\hline & R https://publons.com/researcher/1449372/alex-plastun/ \\
\hline & Nataliya Strochenko (D https://orcid.org/0000-0002-4721-9523 \\
\hline & Olga Zhmaylova (D https://orcid.org/0000-0002-1157-1453 \\
\hline & R https://publons.com/researcher/2455018/olga-zhmaylova/ \\
\hline & Liudmyla Sliusareva (D https://orcid.org/0000-0002-6845-9307 \\
\hline & \multirow{2}{*}{$\begin{array}{l}\text { R https://publons.com/researcher/3274065/liudmyla-sliusareva/ } \\
\text { Sergiy Bashlay D https://orcid.org/0000-0002-2247-5440 }\end{array}$} \\
\hline & \\
\hline ARTICLE INFO & $\begin{array}{l}\text { Alex Plastun, Nataliya Strochenko, Olga Zhmaylova, Liudmyla Sliusareva and } \\
\text { Sergiy Bashlay (2020). Momentum and contrarian effects in the Ukrainian stock } \\
\text { market: case of daily overreactions. Investment Management and Financial } \\
\text { Innovations, } 17(1), 24-34 \text {. doi:10.21511/imfi.17(1).2020.03 }\end{array}$ \\
\hline DOI & http://dx.doi.org/10.21511/imfi.17(1).2020.03 \\
\hline RELEASED ON & Monday, 10 February 2020 \\
\hline RECEIVED ON & Thursday, 28 November 2019 \\
\hline ACCEPTED ON & Friday, 20 December 2019 \\
\hline & $(\mathrm{cc}) \mathrm{EY}$ \\
\hline LICENSE & $\begin{array}{l}\text { This work is licensed under a Creative Commons Attribution } 4.0 \text { International } \\
\text { License }\end{array}$ \\
\hline JOURNAL & "Investment Management and Financial Innovations" \\
\hline ISSN PRINT & $1810-4967$ \\
\hline ISSN ONLINE & $1812-9358$ \\
\hline PUBLISHER & LLC "Consulting Publishing Company "Business Perspectives" \\
\hline FOUNDER & LLC "Consulting Publishing Company "Business Perspectives" \\
\hline & 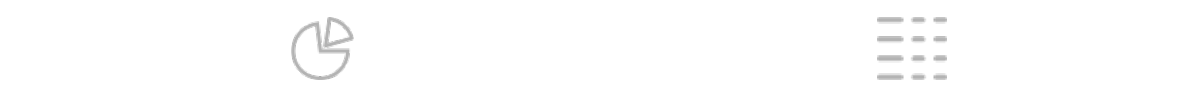 \\
\hline NUMBER OF REFERENCES & NUMBER OF FIGURES \\
\hline 28 & 6 \\
\hline
\end{tabular}

(c) The author(s) 2022. This publication is an open access article. 


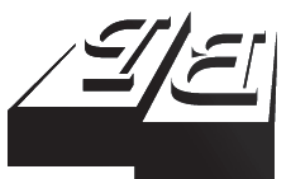

BUSINESS PERSPECTIVES

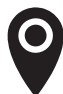

LLC "CPC "Business Perspectives" Hryhorii Skovoroda lane, 10, Sumy, 40022, Ukraine

www.businessperspectives.org

Received on: $28^{\text {th }}$ of November, 2019 Accepted on: $20^{\text {th }}$ of December, 2019

(C) Alex Plastun, Nataliya Strochenko, Olga Zhmaylova, Liudmyla

Sliusareva, Sergiy Bashlay, 2020

Alex Plastun, Ph.D., Professor, Sumy State University, Ukraine.

Nataliya Strochenko, Ph.D., Professor, Sumy National Agrarian University, Ukraine.

Olga Zhmaylova, Ph.D., Associate Professor, Sumy National Agrarian University, Ukraine.

Liudmyla Sliusareva, Ph.D., Associate Professor, University of the State Fiscal Service of Ukraine, Ukraine.

Sergiy Bashlay, Ph.D., Associate Professor, Sumy National Agrarian University, Ukraine.

\section{(ㄷ)(ㄱ)}

This is an Open Access article, distributed under the terms of the Creative Commons Attribution 4.0 International license, which permits unrestricted re-use, distribution, and reproduction in any medium, provided the original work is properly cited.
Alex Plastun (Ukraine), Nataliya Strochenko (Ukraine), Olga Zhmaylova (Ukraine), Liudmyla Sliusareva (Ukraine), Sergiy Bashlay (Ukraine)

\section{MOMENTUM AND CONTRARIAN EFFECTS IN THE UKRAINIAN STOCK MARKET: CASE OF DAILY OVERREACTIONS}

\begin{abstract}
This paper examines momentum and contrarian effects in the Ukrainian stock market after one-day abnormal returns. To do this, UX futures data over the period 2010-2018 are used. The following hypotheses are tested: $\mathrm{H1}$ ) hourly returns on overreaction days differ from hourly returns on normal days, $\mathrm{H} 2$ ) there are price patterns on overreaction days, and $\mathrm{H} 3$ ) to test these hypotheses, visual inspection and average analysis are used, as well as t-tests, cumulative abnormal returns, and trading simulation approaches. The results suggest that there are statistically significant differences between intraday dynamics during the usual days and the overreactions day. There is a strong momentum effect present on the day of overreaction: prices tend to change only in the direction of the overreaction during the whole day. The fact of the overreaction becomes clear after 13:00-14:00. This gives a lot of time to explore the momentum effect in the day of overreaction. On the day after the overreaction, prices tend to go in the opposite direction: contrarian pattern is detected, which is in line with the overreaction hypothesis. Based on detected price patterns, rules of trading and trading strategies for the Ukrainian stock market are developed. Momentum Strategy (based on price patterns on the day of overreaction) generates several successful trades; close to with $90 \%$, and their number being is profitable (trading results differ from the random ones - confirmed by t-tests). Contrarian Strategy (based on price patterns on the day after the overreaction) demonstrates low efficiency, and results do not differ from random trading.
\end{abstract}

\section{Keywords}

Ukrainian stock market, contrarian effect, momentum effect, overreactions, abnormal returns, patterns

JEL Classification

G12, G17, C63

\section{INTRODUCTION}

Despite the theoretical impossibility of price patterns existence in the financial markets (Efficient Market Hypothesis - EMH, see Fama, 1965 for details), there is much empirical evidence in their favor. Among them are calendar anomalies (day of the week effect, month of the year effect, Halloween effect, turn of the month effect, etc.), price reactions and dependence on different variables (economic and political factors), price behavior after force majeure events, and many others including price overreactions.

Overreactions are significant deviations of asset prices from their average values during certain periods (Hong \& Stein, 1999). These periods can be months long (De Bondt \& Thaler, 1985), but can last days as well (Atkins \& Dyl, 1990). From the position of price distribution, overreactions are fat tails or abnormal returns (Plastun, Makarenko, Khomutenko, Belinska, \& Domashenko, 2018).

General consensus in academic literature is as follows: after the overreactions, prices tend to move in the opposite direction (Jegadeesh \& 
Titman, 1993; Ferri \& Min, 1996). So contrarian effect is observed. But for some cases (like cryptocurrency market) momentum effect after one-day abnormal returns is detected (Caporale \& Plastun, 2019).

Despite decades of attention paid to the market overreactions, there are still objects of interest and unexplored aspects. One of them is overreaction microstructure. What is going on inside the market overreaction? Are there any differences in intraday behavior on prices on days of overreaction and usual days? Are there any specific patterns? Can they be exploited? What is going on after the day of overreaction if we will look at this day under the microscope? Answers to these questions can be interesting both for academics and practitioners.

The present paper aims to analyze these aspects and to fill the existing gaps in the overreaction theory. One more motivation is to explore the Ukrainian stock market, which is relatively unexplored in the academic literature: there only a few studies on anomalies in the Ukrainian stock market (Caporale \& Plastun, 2017). To do this, we analyze data from Ukrainian stock exchange by focusing on UX futures (UX is a leading Ukrainian stock market index) over the period from May 18, 2010 till June 15, 2018. Overreactions are the defined by using dynamic trigger values approach (Wong, 1997) and are divided into two data sets: positive and negative overreactions. Then various hypotheses of interest are tested to see whether intraday behavior of hourly returns on days of overreaction differs from those on usual days, and are there any patterns in intraday price dynamics on days of overreaction and after the days of overreaction. For this purpose, a variety of statistical methods, as well as cumulative abnormal returns and trading simulation approaches, are used.

\section{LITERATURE REVIEW}

Abnormal price changes in the financial markets are the object of interest both from the academicians and practitioners. Academicians are interested in their drivers (Aiyagari \& Gertler, 1999; Larson \& Madura, 2001), specifics and properties of market overreactions (De Bondt \& Thaler, 1985), possible patterns in price behavior as the result of market overreactions (Bremer \& Sweeney, 1997; Ferri \& Min, 1996; Caporale, Gil-Alana, \& Plastun, 2018) and effects on market participants (Savor, 2012; Feldman, Livnat, \& Zhang, 2012).

Reasons for overreactions include emotions and herd effects (Griffin \& Tversky, 1992), existence of "noise" traders (Aiyagari \& Gertler, 1999; Hong \& Stein, 1999), overconfidence and other behavioral effects (Daniel, Hirshleifer, \& Subrahmanyam, 1998), the use of technical and fundamental analysis by investors in making the decisions (Duran \& Caginalp, 2007), liquidity in the market (Jegadeesh \& Titman, 1993), different shocks (Subing, Kusumah, \& Gusni, 2017), and others.

Practitioners are concentrated on their exploitation by developing specific trading strategies (Jegadeesh \& Titman, 1993; Caporale et al., 2018;
Caporale \& Plastun, 2019). For example, Caporale et al. (2018) show that it is possible to generate abnormal returns from a strategy based on overreactions. At the same time, overreactions are financial risks and require appropriate efforts to manage them (Shkolnyk, Bondarenko, \& Balatskyi, 2019; Zhuravka, Makarenko, Osetskyi, Podmarov, \& Chentsov, 2019).

Hundreds of papers analyzed the overreactions in the different markets (stock market, FOREX, commodities, etc.), different countries (both developed and emerging), different time frequencies (daily, weekly, monthly, etc.) and different assets (currency pairs, stocks, oil, gold, and many others). General consensus was summarized by so-called overreaction hypothesis: if investors overreact in a given period, they are expected to move in the opposite direction in the following period. A lot of empirical evidence was detected in this favor since the 80-s of the XX century. Among them are Brown, Harlow, and Tinic (1988), Atkins and Dyl (1990), Ferri and Min (1996), who confirmed the overreaction hypothesis in the US stock market; Fung (1999) confirms overreactions in the Hong Kong stock market; Gunaratne and Yonesawa (1997) analyzed return reversals after overreactions in the Tokyo stock exchange; Lobe and 
Rieks (2011) find significant evidence of overreaction on the Frankfurt stock exchange; Maher and Parikh (2011) find abnormal volatility patterns in the Indian stock market; Cutler, Poterba, and Summers (1991) find the evidence in the gold market; Larson and Madura (2003) analyzed the case of the FOREX.

Despite a very large number of papers devoted to the price overreactions, the question of overreaction microstructure is still unexplored. The present study is the first to conduct a systematic analysis of Ukrainian stock market behavior during a day of overreaction and the day after.

\section{DATA AND METHODOLOGY}

Data include daily and hourly prices for the UX futures (UX was one of the leading stock market indexes in Ukraine). The sample period is from May 18, 2010 till June 15, 2018, and the data source is Ukrainian exchange (http://www.ux.ua/).

Daily returns $D R_{i}$ are computed as follows:

$$
\begin{gathered}
R_{i}=\left(\frac{\text { Close }_{i}}{\text { Open }_{i}}-1\right) \cdot 100 \%, \\
D R_{i}=\left(\frac{\text { Close }_{i}}{\text { Close }_{i-1}}-1\right) \cdot 100 \%,
\end{gathered}
$$

where $D R_{i}$ - daily returns in \% on the day $i$, Close $_{i-1}$ - close price on the day $i-1$, Close $_{i}-$ close price on the day $i$.

Hourly returns $H R_{i}$ are computed the same way:

$$
\begin{aligned}
R_{i} & =\left(\frac{\text { Close }_{i}}{\text { Open }_{i}}-1\right) \cdot 100 \%, \\
H R_{i} & =\left(\frac{\text { HClose }_{i}}{\text { HClose }_{i-1}}-1\right) \cdot 100 \%,
\end{aligned}
$$

where $H R_{i}$ - hourly returns in \% on the hour $i$, HClose $_{i-1}$ - close price on the $i-1$ hour, HClose $_{i}$ - close price on the $i$ hour.

Positive/negative overreactions are defined based on the standard deviations to be added/extracted to/from the average return. In order to deal with the most abnormal cases, the number of standard deviations is 2 .

Days with positive abnormal returns (positive overreactions) are defined as follows:

$$
D R_{i}>\left(\bar{R}_{n}+2 \cdot \delta_{n}\right)
$$

Days with negative abnormal returns (negative overreactions) as:

$$
D R_{i}>\left(\bar{R}_{n}-2 \cdot \delta_{n}\right)
$$

where $\bar{R}_{n}$ is the average size of daily returns for period $n$, and $\delta_{n}$ is the standard deviation of daily returns for period $n$.

The following hypotheses are tested in this paper:

H1: Behavior of hourly returns on overreaction days differs from hourly returns on normal days.

H2: There are price patterns on overreaction days.

H3: There are price patterns after overreaction days.

To test these hypotheses, visual inspection and average analysis are used, as well as $t$-tests, cumulative abnormal returns, and trading simulation approaches.

In this paper, we use modified cumulative abnormal returns approach (CAR) proposed by Caporale and Plastun (2019). The cumulative abnormal return denoted as $C A R_{i}$ is simply the sum of the abnormal returns:

$$
C A R_{i}=\sum_{i=1}^{24} A R_{i},
$$

where $A R_{i}$ - abnormal hourly returns defined as:

$$
A R_{t}=R_{t}-E\left(R_{t}\right)
$$

where $R_{t}$ is hourly return at time $t$ and $E\left(R_{t}\right)$ is corresponding average return computed over the whole sample period as follows: 


$$
E\left(R_{t}\right)=\left(\frac{1}{T}\right) \sum_{i=1}^{T} R_{i}
$$

where $T$ is the sample size.

The trading simulation approach aims to replicate the actions of traders by using appropriate algorithms for trading strategies based on the detected anomalies. This allows establishing whether the detected price patterns can be exploited to generate abnormal profits. Indicators of efficiency are profits from trading and percentage of successful trades.

To make sure that simulated trading results are statistically different from the random trading ones, $t$-tests are carried out.

There are some limitations to the variation of the trading simulation approach used in this paper. Transaction costs such as spreads, broker or bank fees, swaps, etc. are not incorporated in the trading results. As a result, real trading efficiency based on the proposed strategies may differ from the simulation. However, nowadays, transaction costs are rather small, and overall results will stay the same.

\section{EMPIRICAL RESULTS}

In order to incorporate possible differences in results for the negative and positive overreactions, we divide the results into two groups. Those for the days with positive abnormal returns and those for the days with negative returns. Next, we divide these data sets into additional sub data sets to explore price behavior on the day of the overreaction and the day after the overreaction. Overall we deal with four sets of data in two time dimensions: daily and hourly.

We start with the day of overreaction data. Visual inspection of price behavior inside the day of overreaction shows the presence of significant differences between returns on the day of overreaction and usual (normal) day (Figures 1 and 2).

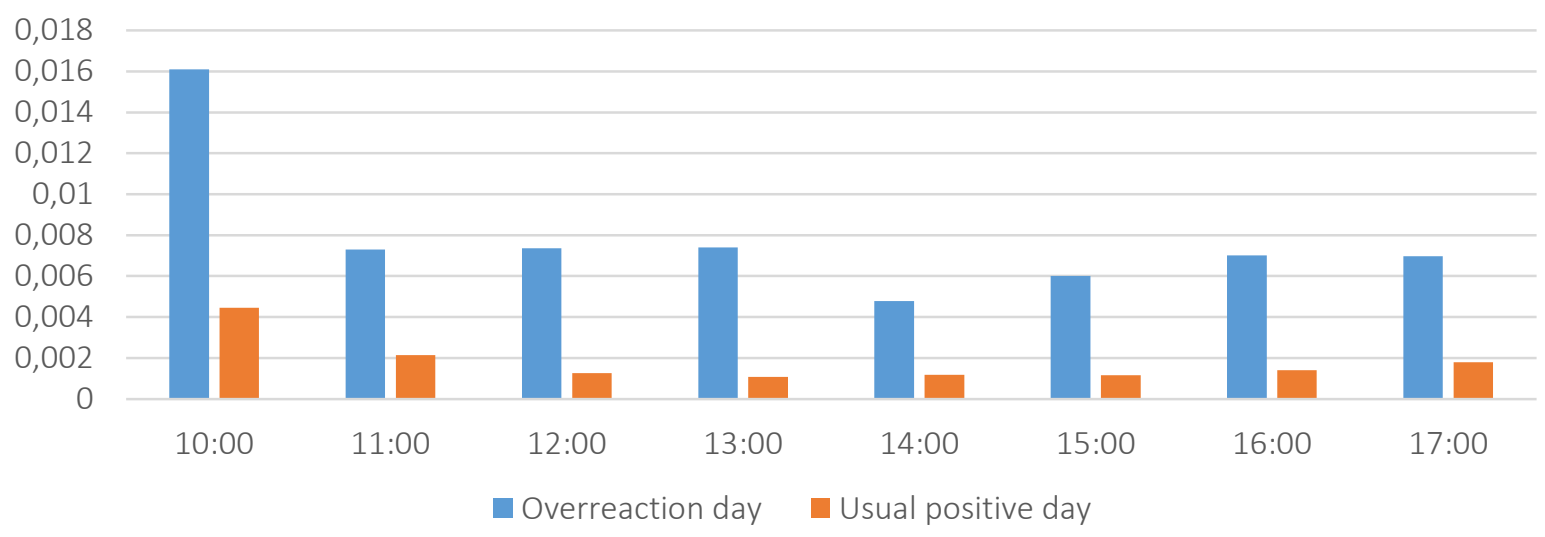

Figure 1. Average hourly returns on overreaction and normal days: the case of positive overreactions, UX-C

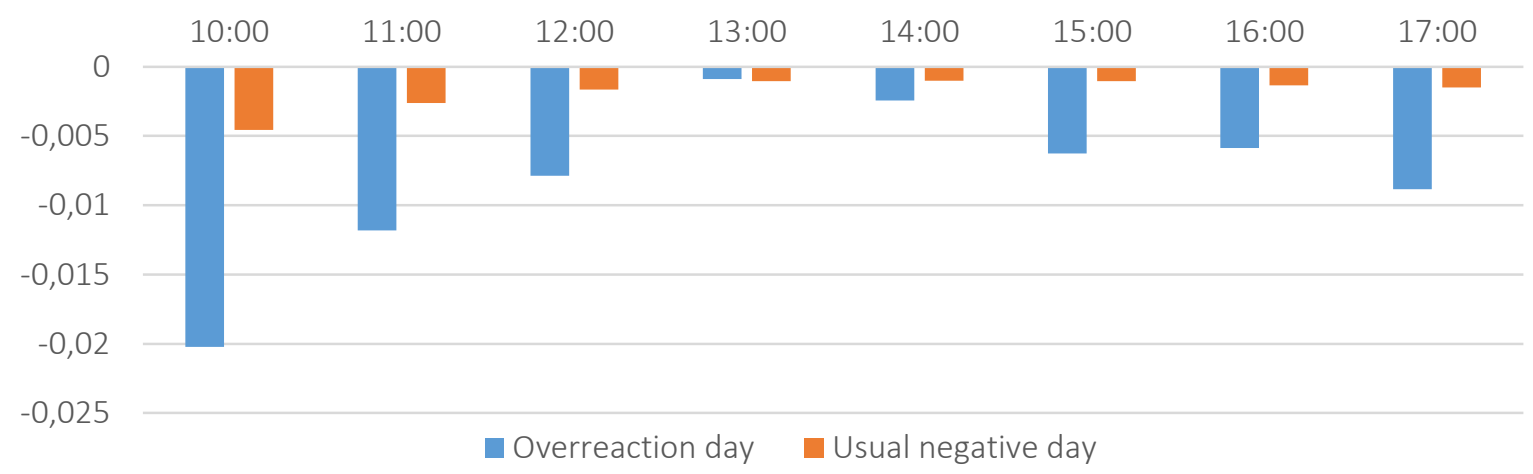

Figure 2. Average hourly returns on overreaction and normal days: the case of negative overreactions, UX-C 
Table 1. $T$-test of hourly returns on overreaction and normal days: the case of positive overreactions, UX-C

\begin{tabular}{c|c|c|c|c|c|c|c}
\hline Hour & $\begin{array}{c}\text { Average return on } \\
\text { positive overreaction } \\
\text { day (OD) }\end{array}$ & $\begin{array}{c}\text { Standard } \\
\text { deviation } \\
\text { (OD) }\end{array}$ & $\begin{array}{c}\text { Number of } \\
\text { observations } \\
\text { (OD) }\end{array}$ & $\begin{array}{c}\text { Average return on } \\
\text { usual day with positive } \\
\text { returns (UD) }\end{array}$ & $\begin{array}{c}\text { Standard } \\
\text { deviation } \\
\text { (UD) }\end{array}$ & $\begin{array}{c}\text { Number of } \\
\text { observations } \\
\text { (UD) }\end{array}$ & $\begin{array}{c}t \\
\text { criterion }\end{array}$ \\
\hline $10: 00$ & $1.61 \%$ & $2.66 \%$ & 47 & $0.45 \%$ & $1.11 \%$ & 755 & 2.98 \\
\hline $11: 00$ & $0.73 \%$ & $1.37 \%$ & 49 & $0.21 \%$ & $0.72 \%$ & 799 & 2.62 \\
\hline $12: 00$ & $0.74 \%$ & $1.02 \%$ & 49 & $0.13 \%$ & $0.58 \%$ & 793 & 4.16 \\
\hline $13: 00$ & $0.74 \%$ & $1.42 \%$ & 50 & $0.11 \%$ & $0.61 \%$ & 764 & 3.14 \\
\hline $14: 00$ & $0.48 \%$ & $1.39 \%$ & 50 & $0.12 \%$ & $0.12 \%$ & $0.59 \%$ & 767 \\
\hline $15: 00$ & $0.60 \%$ & $1.10 \%$ & 49 & $0.56 \%$ & 777 & 3.06 \\
\hline $16: 00$ & $0.70 \%$ & $1.25 \%$ & 50 & $0.14 \%$ & $0.64 \%$ & 815 & 3.15 \\
\hline $17: 00$ & $0.70 \%$ & $1.03 \%$ & 31 & $0.18 \%$ & $0.56 \%$ & 396 & 2.76 \\
\hline
\end{tabular}

Table 2. T-test of hourly returns on overreaction and normal days: the case of negative overreactions, UX-C

\begin{tabular}{|c|c|c|c|c|c|c|c|}
\hline Hour & $\begin{array}{c}\text { Average return on } \\
\text { negative overreaction } \\
\text { day (OD) }\end{array}$ & $\begin{array}{l}\text { Standard } \\
\text { deviation } \\
\text { (OD) }\end{array}$ & $\begin{array}{l}\text { Number of } \\
\text { observations } \\
\text { (OD) }\end{array}$ & $\begin{array}{c}\text { Average return on } \\
\text { usual day with negative } \\
\text { returns (UD) }\end{array}$ & $\begin{array}{l}\text { Standard } \\
\text { deviation } \\
\text { (UD) }\end{array}$ & $\begin{array}{c}\text { Number of } \\
\text { observations } \\
\text { (UD) }\end{array}$ & $\begin{array}{c}t \\
\text { criterion }\end{array}$ \\
\hline 10:00 & $-2.02 \%$ & $2.80 \%$ & 43 & $-0.46 \%$ & $1.15 \%$ & 820 & -3.65 \\
\hline 11:00 & $-1.18 \%$ & $1.41 \%$ & 45 & $-0.26 \%$ & $0.81 \%$ & 857 & -4.34 \\
\hline $12: 00$ & $-0.79 \%$ & $1.04 \%$ & 41 & $-0.17 \%$ & $0.61 \%$ & 853 & -3.79 \\
\hline 13:00 & $-0.09 \%$ & $1.15 \%$ & 42 & $-0.10 \%$ & $0.53 \%$ & 844 & 0.09 \\
\hline $14: 00$ & $-0.24 \%$ & $0.79 \%$ & 44 & $-0.10 \%$ & $0.51 \%$ & 839 & -1.19 \\
\hline $15: 00$ & $-0.63 \%$ & $1.37 \%$ & 43 & $-0.10 \%$ & $0.64 \%$ & 850 & -2.49 \\
\hline $16: 00$ & $-0.59 \%$ & $1.29 \%$ & 42 & $-0.13 \%$ & $0.65 \%$ & 885 & -2.25 \\
\hline $17: 00$ & $-0.88 \%$ & $1.07 \%$ & 23 & $-0.15 \%$ & $0.55 \%$ & 440 & -3.27 \\
\hline
\end{tabular}

To show that these differences are statistically significant, we perform $t$-tests (Tables 1 and 2). T-test statistics confirm that these differences are statistically significant: hourly returns on overreaction days are statistically higher (lower) than those on usual days.

Another important observation is persistence of price dynamics during the overreaction day: on day of positive abnormal returns, prices tend to increase during the whole day and to decrease on days with negative abnormal returns (Figure 3).

To show that this observation has practical implications and generate important information about prices in the Ukrainian stock market and their behavior, we perform CAR analysis (Table 3).

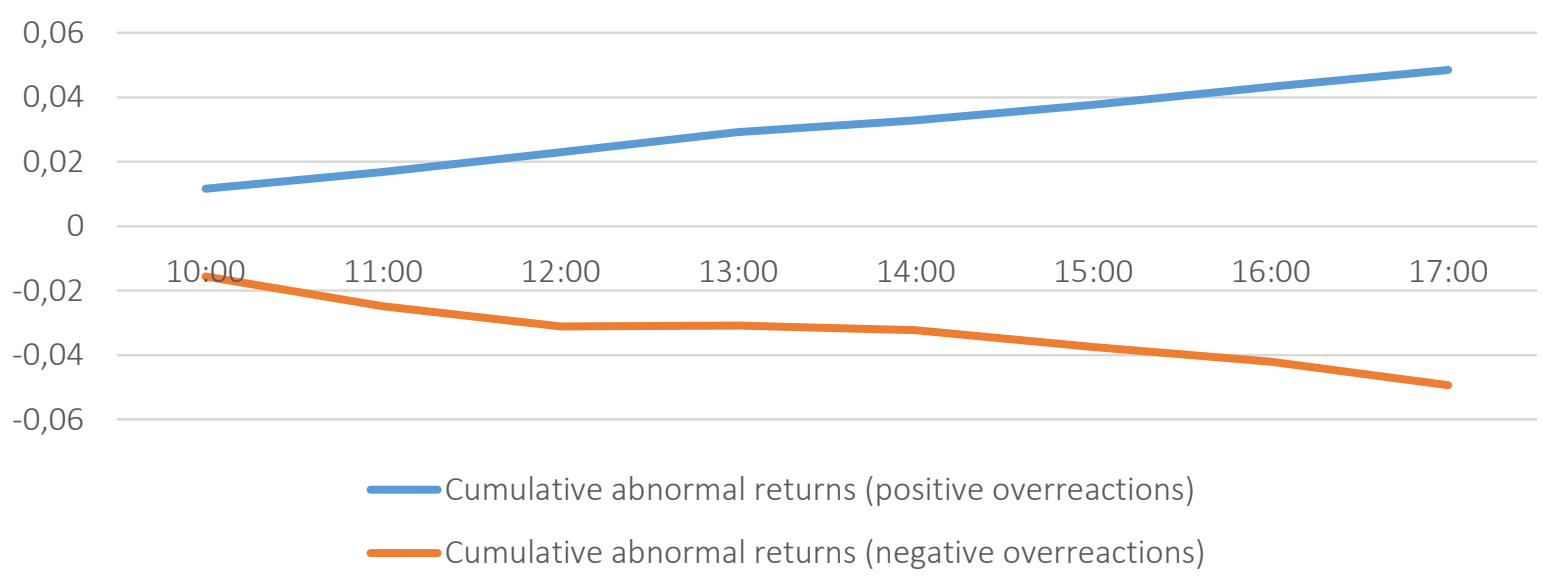

Figure 3. Dynamics of cumulative abnormal returns: case of UX-C 
Table 3. Cumulative abnormal returns: case of positive and negative overreactions, UX-C

\begin{tabular}{|c|c|c|c|c|c|c|}
\hline \multirow{2}{*}{ Hour } & \multicolumn{3}{|c|}{ Positive overreactions } & \multicolumn{3}{|c|}{ Negative overreactions } \\
\hline & Abnormal returns & CAR & Overreaction cross & Abnormal returns & CAR & Overreaction cross \\
\hline 10:00 & $1.16 \%$ & $1.16 \%$ & $2.32 \%$ & $-1.57 \%$ & $-1.57 \%$ & $-1.98 \%$ \\
\hline $11: 00$ & $0.52 \%$ & $1.68 \%$ & $1.59 \%$ & $-0.92 \%$ & $-2.49 \%$ & $-0.80 \%$ \\
\hline $12: 00$ & $0.61 \%$ & $2.29 \%$ & $0.86 \%$ & $-0.62 \%$ & $-3.11 \%$ & $-0.01 \%$ \\
\hline 13:00 & $0.63 \%$ & $2.92 \%$ & $0.12 \%$ & $0.02 \%$ & $-3.09 \%$ & $0.08 \%$ \\
\hline $14: 00$ & $0.36 \%$ & $3.28 \%$ & $-0.36 \%$ & $-0.14 \%$ & $-3.23 \%$ & $0.32 \%$ \\
\hline $15: 00$ & $0.48 \%$ & $3.76 \%$ & $-0.96 \%$ & $-0.52 \%$ & $-3.76 \%$ & $0.95 \%$ \\
\hline $16: 00$ & $0.56 \%$ & $4.32 \%$ & $-1.66 \%$ & $-0.45 \%$ & $-4.21 \%$ & $1.53 \%$ \\
\hline 17:00 & $0.52 \%$ & $4.84 \%$ & $-2.36 \%$ & $-0.73 \%$ & $-4.94 \%$ & $2.42 \%$ \\
\hline
\end{tabular}

Table 4. Trading simulation results for the day of overreaction: case of the Momentum Strategy

\begin{tabular}{|c|c|c|c|c|c|c|c|}
\hline $\begin{array}{l}\text { Number of } \\
\text { trades, units }\end{array}$ & $\begin{array}{c}\text { Number of } \\
\text { successful trades, } \\
\text { units }\end{array}$ & $\begin{array}{c}\text { Number of } \\
\text { successful trades, \% }\end{array}$ & Profit, \% & $\begin{array}{l}\text { Profit, \% } \\
\text { per year }\end{array}$ & $\begin{array}{l}\text { Profit, } \% \\
\text { per trade }\end{array}$ & $\begin{array}{c}t \text {-test } \\
\text { calculated } \\
\text { value }\end{array}$ & $\begin{array}{l}t \text {-test } \\
\text { status }\end{array}$ \\
\hline \multicolumn{8}{|c|}{ Positive overreactions } \\
\hline 51 & 44 & $86 \%$ & $116.80 \%$ & $11.68 \%$ & $2.29 \%$ & 8.01 & Rejected \\
\hline \multicolumn{8}{|c|}{ Negative overreactions } \\
\hline 43 & 38 & $88 \%$ & $100.81 \%$ & $12.60 \%$ & $2.34 \%$ & 6.81 & Rejected \\
\hline
\end{tabular}

Parameter "Overreaction cross" shows a moment when the actual prices exceed the size of return to detect overreaction. As can be seen for the case of positive overreactions, it is 14:00 and 13:00 for the negative overreactions. It means that in general, in the middle of the day, it can be concluded that we have an overreaction day. As a result, traders and investors have sufficient time to exploit momentum effect on the day of overreaction.

To see whether detected momentum effect gives rise to exploitable trading opportunities, the following momentum trading strategy is developed. Momentum Strategy: when it becomes clear that the current day is an overreaction day (the timing of overreaction parameter is provided in Table 3), a position in the direction of overreaction should be opened. This position should then be closed at the end of the day.

The trading simulation results for the Momentum Strategy are presented in Table 4.

As can be seen, detected price pattern can act as a basis for the efficient trading strategy. A number of successful trades is close to $90 \%$, the strategy is profitable, and this is not the result of coincidence ( $t$-test is passed - trading results differ from the random ones).

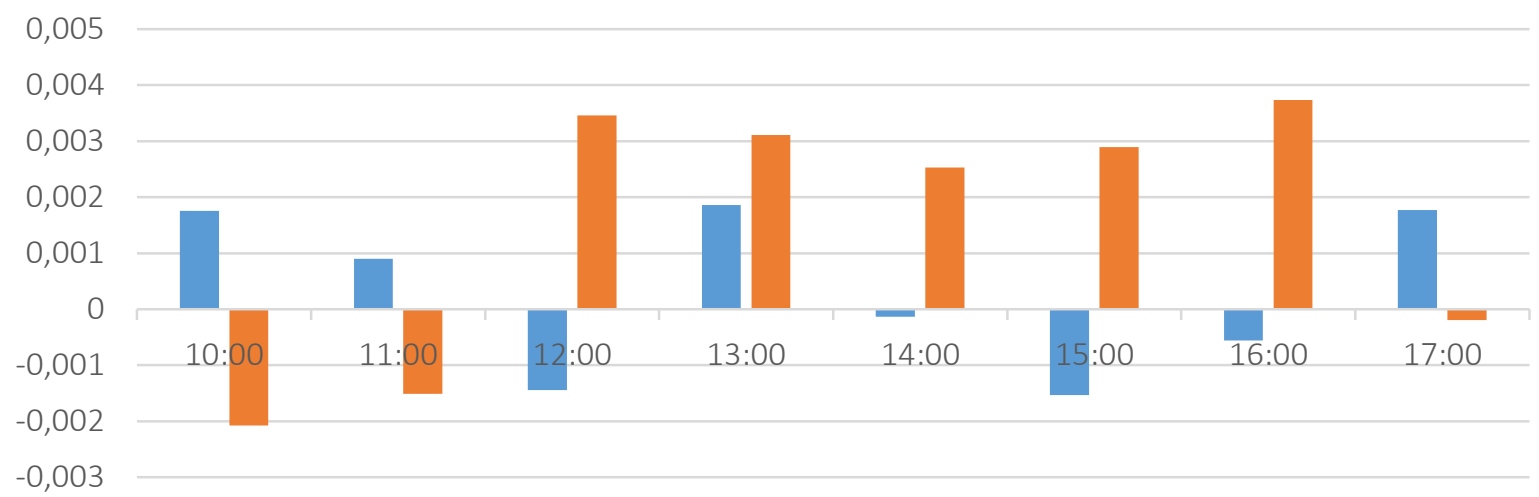

Day after the overreaction Usual day

Figure 4. Average hourly returns on the day after the overreaction and normal days: case of positive overreactions, UX-C 


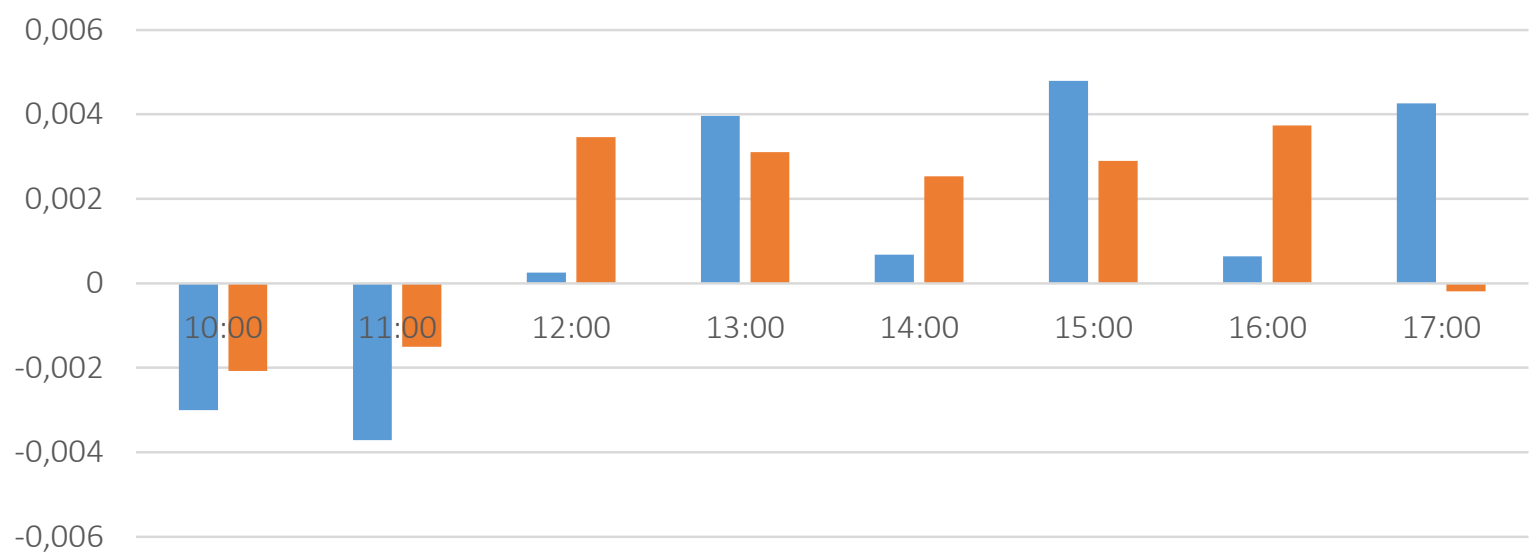

Day after the overreaction $\quad$ Usual day

Figure 5. Average hourly returns on the day after the overreaction and normal days: the case of negative overreactions, UX-C

Concerning price behavior on the day after overreactions, average hourly returns in the Ukrainian stock market after positive and negative overreactions differ from those on normal days (Figures 4 and 5).
But these differences are statistically significant (Tables 5 and 6) only for selected hours for the case of positive overreactions.

Behavior of cumulative abnormal returns (Table 7 and Figure 6) evidence in favor of contrarian ef-

Table 5. $T$-test of hourly returns on the day after the overreaction and normal days: case of positive overreactions, UX-C

\begin{tabular}{|c|c|c|c|c|c|c|c|}
\hline Hour & $\begin{array}{l}\text { Average return on } \\
\text { day after positive } \\
\text { overreaction (OD) }\end{array}$ & $\begin{array}{c}\text { Standard } \\
\text { deviation } \\
\text { (OD) }\end{array}$ & $\begin{array}{c}\text { Number of } \\
\text { observations } \\
\text { (OD) }\end{array}$ & $\begin{array}{c}\text { Average return } \\
\text { on usual day } \\
\text { (UD) }\end{array}$ & $\begin{array}{c}\text { Standard } \\
\text { deviation } \\
\text { (UD) }\end{array}$ & $\begin{array}{c}\text { Number of } \\
\text { observations } \\
\text { (UD) }\end{array}$ & $\begin{array}{c}t \\
\text { criterion }\end{array}$ \\
\hline 10:00 & $0.18 \%$ & $2.47 \%$ & 49 & $-0.21 \%$ & $1.60 \%$ & 1593 & 1.08 \\
\hline $11: 00$ & $0.09 \%$ & $1.43 \%$ & 50 & $-0.15 \%$ & $2.02 \%$ & 1680 & 1.16 \\
\hline $12: 00$ & $-0.14 \%$ & $1.16 \%$ & 49 & $0.35 \%$ & $0.86 \%$ & 1670 & -2.94 \\
\hline $13: 00$ & $0.19 \%$ & $1.39 \%$ & 48 & $0.31 \%$ & $1.47 \%$ & 1628 & -0.61 \\
\hline $14: 00$ & $-0.01 \%$ & $1.29 \%$ & 49 & $0.25 \%$ & $1.39 \%$ & 1624 & -1.43 \\
\hline $15: 00$ & $-0.15 \%$ & $0.98 \%$ & 50 & $0.29 \%$ & $1.25 \%$ & 1653 & -3.11 \\
\hline $16: 00$ & $-0.06 \%$ & $0.95 \%$ & 51 & $0.37 \%$ & $1.29 \%$ & 1722 & -3.14 \\
\hline $17: 00$ & $0.18 \%$ & $0.78 \%$ & 33 & $-0.02 \%$ & $0.59 \%$ & 840 & 1.43 \\
\hline
\end{tabular}

Table 6. $T$-test of hourly returns on the day after the overreaction and normal days: case of negative overreactions, UX-C

\begin{tabular}{|c|c|c|c|c|c|c|c|}
\hline Hour & $\begin{array}{l}\text { Average return on } \\
\text { day after negative } \\
\text { overreaction (OD) }\end{array}$ & $\begin{array}{l}\text { Standard } \\
\text { deviation } \\
\text { (OD) }\end{array}$ & $\begin{array}{l}\text { Number of } \\
\text { observations } \\
\text { (OD) }\end{array}$ & $\begin{array}{l}\text { Average return } \\
\text { on usual day } \\
\text { (UD) }\end{array}$ & $\begin{array}{l}\text { Standard } \\
\text { deviation } \\
\text { (UD) }\end{array}$ & $\begin{array}{l}\text { Number of } \\
\text { observations } \\
\text { (UD) }\end{array}$ & $\begin{array}{c}t \\
\text { criterion }\end{array}$ \\
\hline 10:00 & $-0.30 \%$ & $2.00 \%$ & 43 & $-0.21 \%$ & $1.60 \%$ & 1593 & -0.30 \\
\hline $11: 00$ & $-0.37 \%$ & $1.40 \%$ & 44 & $-0.15 \%$ & $2.02 \%$ & 1680 & -1.01 \\
\hline $12: 00$ & $0.03 \%$ & $1.33 \%$ & 41 & $0.35 \%$ & $0.86 \%$ & 1670 & -1.53 \\
\hline $13: 00$ & $0.40 \%$ & $1.50 \%$ & 41 & $0.31 \%$ & $1.47 \%$ & 1628 & 0.36 \\
\hline $14: 00$ & $0.07 \%$ & $1.25 \%$ & 44 & $0.25 \%$ & $1.39 \%$ & 1624 & -0.97 \\
\hline $15: 00$ & $0.48 \%$ & $1.17 \%$ & 42 & $0.29 \%$ & $1.25 \%$ & 1653 & 1.03 \\
\hline $16: 00$ & $0.06 \%$ & $1.76 \%$ & 43 & $0.37 \%$ & $1.29 \%$ & 1722 & -1.14 \\
\hline $17: 00$ & $0.43 \%$ & $1.24 \%$ & 23 & $-0.02 \%$ & $0.59 \%$ & 840 & 1.72 \\
\hline
\end{tabular}


Table 7. Cumulative abnormal returns: case of positive and negative overreactions, UX-C

\begin{tabular}{c|c|c|c|c}
\hline \multirow{2}{*}{ Hour } & \multicolumn{2}{|c}{ Positive overreactions } & \multicolumn{2}{c}{ Negative overreactions } \\
\cline { 2 - 4 } & Abnormal returns & Cumulative abnormal returns & Abnormal returns & Cumulative abnormal returns \\
\hline $10: 00$ & $0.38 \%$ & $0.38 \%$ & $-0.09 \%$ & $-0.09 \%$ \\
$11: 00$ & $0.24 \%$ & $0.62 \%$ & $-0.22 \%$ & $0.13 \%$ \\
\hline $12: 00$ & $-0.49 \%$ & $0.13 \%$ & $-0.32 \%$ & $0.45 \%$ \\
$13: 00$ & $-0.12 \%$ & $0.01 \%$ & $0.09 \%$ & $0.36 \%$ \\
$14: 00$ & $-0.27 \%$ & $-0.26 \%$ & $-0.19 \%$ & $0.55 \%$ \\
$15: 00$ & $-0.44 \%$ & $-0.70 \%$ & $-19 \%$ & $0.36 \%$ \\
$16: 00$ & $-0.43 \%$ & $-1.13 \%$ & $-0.31 \%$ & $0.67 \%$ \\
\hline $17: 00$ & $0.20 \%$ & $-0.93 \%$ & $0.45 \%$ & $0.22 \%$ \\
\hline
\end{tabular}

fect: on the following day, prices tend to move in the direction opposite to the overreaction.

Based on Table 7, specific price patterns and their timings can be determined. For example, there is a certain momentum effect during first 2 hours of trading on the day after the overreaction, but all the rest of time - strong evidence in favor of contrarian effect is detected.

Based on these results, the following trading strategy can be developed. Contrarian Strategy (basic): at the beginning of the trading session (at 10:00) after the overreaction, a position in the direction opposite to the overreaction should be opened. This position should be closed on the end of the day.

Contrarian Strategy (modified): at 12:00, a position in the direction opposite to the overreaction should be opened. This position should be closed at the end of the day.

The trading simulation results for the Contrarian Strategy is presented in Table 8.
As can be seen, modified strategy provides better results. But overall, Contrarian Strategy demonstrates low efficiency, and results do not differ from random trading.

Overall findings of this paper can be summarized as follows:

1. There are differences between intraday dynamics during the usual days and the overreactions day. For most of the cases, these differences are statistically significant.

2. There is a strong momentum effect present on the day of overreaction: prices tend to change only in the direction of the overreaction during the whole day.

3. Usually, the fact of the overreaction becomes clear after 13:00-14:00. This gives a lot of time to explore the momentum effect in the day of overreaction.

4. The overreaction hypothesis is confirmed: there is a contrarian pattern present (on the

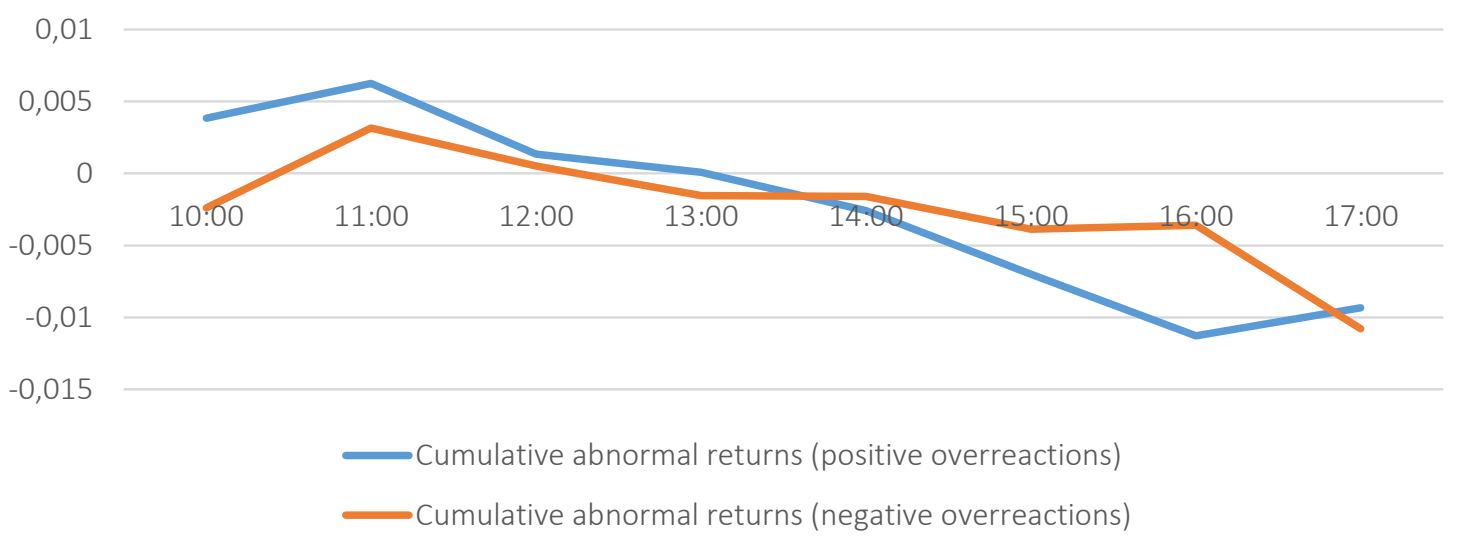

Figure 6. Dynamics of cumulative abnormal returns, UX-C 
Table 8. Trading simulation results for the day after the overreaction: case of the Contrarian Strategy

\begin{tabular}{|c|c|c|c|c|c|c|c|}
\hline $\begin{array}{l}\text { Number of } \\
\text { trades, units }\end{array}$ & $\begin{array}{c}\text { Number of } \\
\text { successful trades, } \\
\text { units }\end{array}$ & $\begin{array}{c}\text { Number of } \\
\text { successful trades, } \\
\%\end{array}$ & $\begin{array}{c}\text { Profit, } \\
\%\end{array}$ & $\begin{array}{l}\text { Profit, } \% \\
\text { per year }\end{array}$ & $\begin{array}{l}\text { Profit, \% } \\
\text { per trade }\end{array}$ & $\begin{array}{c}t \text {-test calculated } \\
\text { value }\end{array}$ & $\begin{array}{l}t \text {-test } \\
\text { status }\end{array}$ \\
\hline \multicolumn{8}{|c|}{ Positive overreactions (basic strategy) } \\
\hline 51 & 31 & $61 \%$ & $-10 \%$ & $-1.29 \%$ & $-0.20 \%$ & -0.40 & $\begin{array}{c}\text { Not } \\
\text { rejected }\end{array}$ \\
\hline \multicolumn{8}{|c|}{ Positive overreactions (modified strategy) } \\
\hline 49 & 27 & $55 \%$ & $5 \%$ & $0.65 \%$ & $0.11 \%$ & 0.32 & $\begin{array}{l}\text { Not } \\
\text { rejected }\end{array}$ \\
\hline \multicolumn{8}{|c|}{ Negative overreactions (basic strategy) } \\
\hline 46 & 20 & $43 \%$ & $3 \%$ & $0.34 \%$ & $0.06 \%$ & 0.11 & $\begin{array}{l}\text { Not } \\
\text { rejected }\end{array}$ \\
\hline \multicolumn{8}{|c|}{ Negative overreactions (modified strategy) } \\
\hline 41 & 25 & $61 \%$ & $28 \%$ & $3.54 \%$ & $0.69 \%$ & 1.67 & $\begin{array}{l}\text { Not } \\
\text { rejected }\end{array}$ \\
\hline
\end{tabular}

day after the overreaction prices tend to go in the opposite direction).

5. Contrarian movement starts 2 hours after the start of the day after the overreaction and lasts till the end of the day.

So, we find confirmations in favor of overreaction hypothesis. But what is most important we define the timing of these processes, which is crucial for practical implications.

As a result, some rules of trading are proposed:

6. When it becomes clear that the overreaction is present, positions in the direction of the overreaction should be opened. These positions should be hold till the end of the day.

7. On the start of the day after the overreaction, contrarian positions to the direction of the overreaction need to be opened. These positions should be hold till the end of the day.
8. To improve the efficiency of the mentioned above trading rules, specific timing parameters calculated in this paper can be used.

Practical implications of this paper are trading strategies developed based on proposed rules of trading:

- Momentum Strategy: when it becomes clear that the current day is an overreaction day (the timing of overreaction parameter is provided in the paper), a position in the direction of overreaction should be opened. This position should then be closed at the end of the day;

- Contrarian Strategy (basic): at the beginning of the trading session (at 10:00) after the overreaction, a position in the direction opposite to the overreaction should be opened. This position should be closed at the end of the day;

Contrarian Strategy (modified): at 12:00, a position in the direction opposite to the overreaction should be opened. This position should be closed at the end of the day.

\section{CONCLUSION}

This paper examines momentum and contrarian effects in the Ukrainian stock market after one-day abnormal returns. To do this historical data for the UX futures (both daily and hourly) over the period from January 1, 2008 till December 31, 2018 are used. Overreactions are detected based on dynamic trigger approach. Several data sets are formed as a result: positive and negative overreactions both for the case of the day of overreaction and day after the overreaction. Intraday price behavior during the day of overreaction and the day after the overreaction is analyzed. To do this, various statistical tests are used, as well as cumulative abnormal returns, and trading simulation approaches. 
The following hypotheses are tested: behavior of hourly returns on overreaction days differs from hourly returns on normal days $(H 1)$, there are price patterns on overreaction days $(H 2)$, and there are price patterns after overreaction days $(H 3)$.

We find statistically significant differences between intraday dynamics during the usual days and overreaction days. There is a strong momentum effect present on the day of overreaction: prices tend to change only in the direction of the overreaction during the whole day. The overreaction hypothesis is confirmed: on the day after overreaction, prices in the Ukrainian stock market tend to move in the opposite direction.

Detected anomalies for the case of overreaction day (momentum effect) are not just statistical phenomena, but real market inefficiencies because they allow generating abnormal profits from trading.

The following trading strategies are developed based on the results of the paper:

- Momentum Strategy: when it becomes clear that the current day is an overreaction day (the timing of overreaction parameter is provided in the paper), a position in the direction of overreaction should be opened. This position should then be closed at the end of the day;

- Contrarian Strategy (basic): at the beginning of the trading session (at 10:00) after the overreaction, a position in the direction opposite to the overreaction should be opened. This position should be closed at the end of the day;

- Contrarian Strategy (modified): at 12:00, a position in the direction opposite to the overreaction should be opened. This position should be closed at the end of the day.

Momentum Strategy generates several successful trades, with their number being close to $90 \%$, and is profitable (trading results differ from the random ones - confirmed by $t$-tests).

Contrarian Strategy demonstrates low efficiency, and results do not differ from random trading.

Results of this paper can be useful both for academicians (additional evidence in favor of the overreaction hypothesis and brand new analysis of the overreaction effects) and practitioners (specific parameters for trading strategies based on market overreactions are defined, concrete trading strategies are developed and tested for the efficiency).

\section{ACKNOWLEDGMENT}

Alex Plastun gratefully acknowledges financial support from the Ministry of Education and Science of Ukraine (0117U003936).

\section{REFERENCES}

1. Aiyagari, S. Rao, \& Gertler, M. (1999). Overreaction of Asset Prices in General Equilibrium. Review of Economic Dynamics, 2(1), 3-35. https://doi.org/10.1006/ redy. 1998.0053

2. Atkins, A. B., \& Dyl, E. A. (1990). Price Reversals, Bid-Ask Spreads, and Market Efficiency. Journal of Financial and Quantitative Analysis, 25(4), 535-547. https:// doi.org/10.2307/2331015

3. Bremer, M., Hiraki, T., \& Sweeney, R. J. (1997). Predictable patterns after large stock price changes on the Tokyo Stock Exchange. Journal of Financial and Quantitative Analysis, 32(3), 345-365. https:// doi.org/10.2307/2331204
4. Brown, K. C., Harlow, W. V., \& Tinic, S. M. (1988). Risk Aversion, Uncertain Information, and Market Efficiency. Journal of Financial Economics, 22(2), 355385. https://doi.org/10.1016/0304405X(88)90075-X

5. Caporale, G. M., \& Plastun, A. (2017). Calendar anomalies in the Ukrainian stock market. 
Investment Management and Financial Innovations, 14(1), 104114. http://dx.doi.org/10.21511/ imfi.14(1).2017.11

6. Caporale, G. M., Gil-Alana, L., \& Plastun, A. (2018). Short-term Price Overreactions: Identification, Testing, Exploitation. Computational Economics, 51(4), 913-940. Retrieved from https:// link.springer.com/article/10.1007/ s10614-017-9651-2

7. Caporale, G., \& Plastun, A. (2019). Price overreactions in the cryptocurrency market. Journal of Economic Studies, 46(5), 11371155. Retrieved from https://ideas. repec.org/p/diw/diwwpp/dp1718. html

8. Cutler, D., Poterba, J., \& Summers, L. (1991). Speculative dynamics. Review of Economics Studies, 58(3), 529-546. https://doi. org/10.2307/2298010

9. Daniel, K., Hirshleifer, D., \& Subrahmanyam, A. (1998). Investor Psychology and Security Market Under- and Overreactions. Journal of Finance, 53, 1839-1886. https://doi.org/10.1111/00221082.00077

10. De Bondt, W., \& Thaler, R. (1985). Does the Stock Market Overreact? Journal of Finance, 40(3), 793-808. https://doi.org/10.2307/2327804

11. Duran, A., \& Caginalp, G. (2007). Overreaction Diamonds: Precursors and Aftershocks for Significant Price Changes. Quantitative Finance, 7(3), 321342. Retrieved from https:// papers.ssrn.com/sol3/papers. cfm?abstract_id=932991

12. Fama, E. F. (1965). The Behavior of Stock-Market Prices. The Journal of Business, 38(1), 34-105. Retrieved from https://www.jstor. org/stable/2350752?seq=1

13. Feldman, R., Livnat, J., \& Zhang, Y. (2012). Analysts' Earnings Forecast, Recommendation and Target Price Revisions. Journal of Portfolio Management, 38(3), 120-132. https://doi.org/10.3905/ jpm.2012.38.3.120

14. Ferri, M. G., \& Min, C. (1996). Evidence that the Stock Market Overreacts and Adjusts. The
Journal of Portfolio Management, 22, 71-76. Retrieved from https:// jpm.pm-research.com/content $/ 22 / 3 / 71$

15. Fung, M. (1999). Overreaction in the Hong Kong stock market. Global Finance Journal, 10(2), 223-230. https://doi.org/10.1016/ S1044-0283(99)00016-2

16. Griffin, D., \& Tversky, A. (1992). The weighing of evidence and the determinants of confidence. Cognitive Psychology, 24(3), 411435. https://doi.org/10.1016/00100285(92)90013-R

17. Gunaratne, P., \& Yonesawa, Y. (1997). Return reversals in the Tokyo stock exchange: A test of stock market overreaction. Japan and the World Economy, 9(3), 363-384. https://doi.org/10.1016/ S0922-1425(96)00256-3

18. Hong, H., \& Stein, J. C. (1999). A Unified Theory of Underreaction, Momentum Trading and Overreaction in Asset Markets. Journal of Finance, 54(6), 2143-2184. https://doi. org/10.1111/0022-1082.00184

19. Jegadeesh, N., \& Titman, S. (1993). Returns to Buying Winners and Selling Losers: Implications for Stock Market Efficiency. The Journal of Finance, 48(1), 65-91. https://doi.org/10.2307/2328882

20. Larson, S., \& Madura, J. (2001). Overreaction and underreaction in the foreign exchange market. Global Finance Journal, 12(2), 153-177. https://doi.org/10.1016/ S1044-0283(01)00026-6

21. Lobe, S., \& Rieks, J. (2011). Shortterm market overreaction on the Frankfurt stock exchange. The Quarterly Review of Economics and Finance, 51(2), 113-123. https://doi.org/10.1016/j. qref.2010.12.002

22. Maher, D., \& Anokhi, P. (2011). Short-term under/overreaction, anticipation or uncertainty avoidance? Evidence from India. Journal of International Financial Markets, Institutions and Money, 21(4), 560-584. https://doi. org/10.1016/j.intfin.2011.03.002

23. Plastun, A., Makarenko, I., Khomutenko, L., Belinska, Y.,
\& Domashenko, M. (2018). Exploring frequency of price overreactions in the Ukrainian stock market. Investment Management and Financial Innovations, 15(3), 157-168. http://dx.doi.org/10.21511/ imfi.15(3).2018.13

24. Savor, P. (2012). Stock Returns after Major Price Shocks: The Impact of Information. Journal of Financial Economics, 106(3), 635-659. https://doi.org/10.1016/j. jfineco.2012.06.011

25. Shkolnyk, I., Bondarenko, E., \& Balatskyi, I. (2019). Financial risks of the stock market: opportunities and specifics of their insurance. Insurance Markets and Companies, 10(1), 26-35. http://dx.doi. org/10.21511/ins.10(1).2019.03

26. Subing, H. J. T., Kusumah, R. W. R., \& Gusni (2017). An empirical analysis of internal and external factors of stock pricing: evidence from Indonesia. Problems and Perspectives in Management, 15(4), 178-187. https://doi.org/10.21511/ ppm.15(4-1).2017.02

27. Wong, M. (1997). Abnormal Stock Returns Following Large One-day Advances and Declines: Evidence from Asian-Pacific Markets. Financial Engineering and Japanese Markets, 4, 171-177. https://doi. org/10.1023/A:1009625931727

28. Zhuravka, F., Makarenko, M., Osetskyi, V., Podmarov, O., \& Chentsov, V. (2019). Impact of politically generated shocks on monetary performance: a cross-country comparison. Banks and Bank Systems, 14(3), 99112. https://doi.org/10.21511/ bbs.14(3).2019.09 